CHAPTER FIVE

\title{
VONDEL'S RELIGION
}

\author{
Judith Pollmann
}

No subject in Vondel's biography has attracted as much scholarly interest as his religious convictions. Brought up as a Mennonite, the poet spent many decades in the circles of Arminian 'Remonstrants', before converting to Catholicism around 1640. Scholarly fascination with the subject of Vondel's conversion peaked between 1860 and 1960, when cultural critics and scholars devoted many gallons of ink to the details of Vondel's religious development. ${ }^{1}$ From the mid-nineteenth century, Dutch Catholics, on the wings of their political emancipation, were busily reclaiming a space for themselves in the cultural history of the nation. Since this was widely acknowledged to have been at its apogee in the seventeenth century, Catholics were particularly keen to emphasize their contribution to this greatness. What better way to do so than to appropriate the greatest poet of the Dutch Golden Age?

The Catholic Vondel scholarship that resulted from this interest was underpinned by what we might call a hermeneutics of Catholic experience. Catholic Vondel scholars believed that their own Catholicism enabled them to better understand Vondel. Since they also had a clear sense of what a conversion should involve, and what a convert should experience, they felt very confident that they could recognize the symptoms of Catholicity and conversion pains in the literary output of their seventeenth-century coreligionist. ${ }^{2}$ Inevitably, non-Catholic Vondel scholars - liberals, moderate Protestants, and even socialists - riposted with their own readings, and continued to foreground the Protestant side of Vondel. Thus there were efforts to bring out the Remonstrant in Vondel, while in 1935 W.A.P. Smit made an attempt to show that, at its core, Vondel's religiosity had always remained that of the Mennonite

\footnotetext{
${ }^{1}$ Spies, 'Nederlands vele Vondels'.

2 Reflections on this hermeneutics can be found in (for instance) Drabbe, Vondel's overgang tot de katholieke kerk. Other examples include: Brom, Vondels bekering; Molkenboer, 'Wanneer werd Vondel katholiek?', pp. 6-7.
} 
doopsgezinden. ${ }^{3}$ Secularists, in the meantime, argued that Vondel's religious development was really not to be taken too seriously. The socialist scholars Jan and Annie Romein even talked of his 'alleged' conversion. ${ }^{4}$ One way or the other, it was the ideological preferences of the authors, rather than those of Vondel, that coloured most of the work on Vondel's religion. ${ }^{5}$

The highly ideological character of the discussion explains why in the 1960s interest in Vondel's religion suddenly collapsed. The secularization process that overwhelmed the Netherlands in that decade turned the poet in general, and his religious affiliation in particular, into a deeply unfashionable topic. For decades, silence surrounded the subject. The latest Vondel biographer, Piet Calis, does no more than carefully adjudicate on the findings in the older literature. ${ }^{6}$ Frans-Willem Korsten's recent study of sovereignty in Vondel's work consciously steers away from an attempt to connect Vondel's views of the divine with a confessional position. ${ }^{7}$ New insights into the religious culture of the Dutch Republic, however, mean that we should be in a much better position to contextualize and compare Vondel's religious sentiments with those of his contemporaries than we used to be. The aim of this chapter is to suggest ways of rethinking Vondel's religious development by reexamining and recontextualizing some of the core evidence on his religious views, without reading between the lines in his dramatic work. In effect, I shall try here to explore Vondel's religion as one might attempt to do for any other seventeenth-century believer, in the hope that a more sober assessment of the evidence can help others towards a new look at the role of religion in his work.

\section{Choice and Certainty}

From the age of eight, when his family moved from Cologne to the Dutch Republic, Vondel lived in a polity that did not have a state

\footnotetext{
${ }^{3}$ Leendertz, 'Is Vondel remonstrant geweest'; Smit, 'Vondel en zijn bekering'; Kühler, Geschiedenis van de doopsgezinden in Nederland, pp. 41-42

${ }^{4}$ Jan and Annie Romein, 'Joost van den Vondel'.

${ }^{5}$ It is no accident that the most clearheaded summary of Vondel's religiosity to date appeared in Melles, Joost van den Vondel, pp. 130-32, whose primary aim was to reconstruct Vondel's finances.

${ }_{6}^{6}$ Calis, Vondel, p. 201.

7 Korsten, Vondel belicht, p. 106; Sovereignty as Inviolabitily, p. 95. He does so by invoking my Religious Choice in the Dutch Republic, but I did not argue that seventeenth-century Netherlanders were uninterested in doctrinal issues, just that their decisions to convert were not necessarily inspired by dogmatic issues alone.
} 
church. The Calvinist Reformed church was known as the public church' - it had the monopoly on religious worship, its ministers were paid for by the secular authorities, and it had the use of the old church buildings. The church was expected to offer prayers for the nation, and to take the lead on days of public penance or thanksgiving. Consistories of the church advised the authorities in matters of morality, education and charity. The church was required to offer some religious services to all comers. Anyone could be baptized in the Reformed church, and the churches also married the non-Reformed (although those nonReformed who could afford it preferred to use the provision for civic marriage that existed in many places). Anyone could be buried in the church buildings and cemeteries around them. Anyone was free to attend sermons. Yet membership of this church was not compulsory quite the opposite, the Reformed churches claimed and retained the right to admit to communion only those who, as adults, had made a confession of faith and who were prepared to submit to church discipline. ${ }^{8}$ Many Dutch believers did not want to do so. By 1600 perhaps only one in ten residents of Amsterdam was a member of the Reformed church; a century later the Reformed still only made up just under half of the urban community - Calvinist church members were always a minority, even if they were the most privileged, among many other minorities. ${ }^{9}$

The fact that such other minorities could continue to thrive was because the Republic guaranteed 'freedom of conscience' to its citizens - no one could be taken to task for his religious beliefs (although in practice, an exception was sometimes made for Socinians and 'atheists'). While, formally, freedom of conscience did not in any way involve freedom of worship, in practice its existence did leave the road open to small religious gatherings in private homes. Especially in cities like Amsterdam, these could develop into semi-legal church communities, which usually paid for the privilege of being left undisturbed. ${ }^{10}$ As a consequence, Amsterdam had a series of well-established Mennonite communities, as well as an emerging underground Catholic subculture, by the time the Vondel family settled there in 1596. In the course of the seventeenth century, many other minority groups also set up their own churches there. Among these, it was especially the Arminian

\footnotetext{
8 Van Deursen, Bavianen en Slijkgeuzen.

9 Spaans, 'Stad van vele geloven, 1578-1798', p. 401.

10 Van Nierop and Po-Chia Hsia, Calvinism and Toleration in the Dutch Republic.
} 
Remonstrant community that was to be important for Vondel. After 1610 a schism emerged in the Dutch Reformed church over the doctrinal issue of double predestination. Followers of the theologian Jacobus Arminius lost their battle for control of the Reformed church, and the so-called Counter-Remonstrants succeeded in imposing their take on the issue of double predestination. The Synod of Dordt of 1618-1619 forced all ministers of the church into line, and expelled all Arminian theologians who refused to abide by its canons. After a few years the Arminians regrouped as the 'Remonstrant brotherhood'.

Geeraardt Brandt, Vondel's contemporary and first biographer, described Vondel's early religious commitments as follows:

In matters of religion he had accepted the doctrine of the Mennonites, according to his parents' teaching, and had, among their many branches, opted to join the community of the Waterlanders, and had served as a deacon among them. Yet when the quarrels among the Remonstrants and Counter-Remonstrants had arrived at their peak, and the former had been condemned $[\ldots]$ he took the side of the underdog, and the injustices that had, so unfairly in his view, been visited upon them, kindled in him a great zeal to defend their cause [...] This caused everyone to say that he had become altogether Remonstrant, although he never took communion with them $[\ldots] .^{11}$

One of the key characteristics of Netherlandish religious life was its confessional fluidity. In the sixteenth century, many people had developed an interest in dissident ideas without necessarily breaking away from the old church. Often it had been the punitive measures of the Habsburg authorities that had forced confessional choice upon those who were forced to recant their beliefs, or to flee into exile and into the arms of refugee communities where a fully fledged form of Protestantism was taught. Because the Dutch Republic did not force its citizens to join the public church, and because many Dutch believers did not seal their religious convictions with church membership, the culture of religious fluidity could continue to exist throughout the Golden Age. By the mid seventeenth century, there were still many believers who refused to become communicant members of a church, and all churches were used to the presence of non-communicant liefhebbers or 'sympathizers.'

${ }^{11}$ Brandt, 'Het leven van Joost van den Vondel', pp. 17-18.

${ }^{12}$ Pollmann, 'From Freedom of Conscience to Confessional Segregation?'. 
After his conversion to Catholicism, Vondel himself described his former Mennonite faith as 'inherited doctrine.'13 With two Mennonite parents, who were prepared to migrate for their faith, he was raised a Mennonite as a matter of course. Yet both in Mennonite and Reformed circles, church membership was not automatically transferred to younger generations. Each generation decided for itself when to join formally - by accepting adult baptism in the Mennonite case, or by making one's confession in the Reformed and Remonstrant communities. Many children, even when brought up in a household in which the parents shared one religion, took their time over committing themselves. Thus Vondel's own daughter, Anna, was still unbaptized when she joined the Catholic church at age 30 - she had apparently felt free to postpone this choice and had thus never become a communicant Mennonite. ${ }^{14}$ Other members of the Vondel family also ignored family commitments when deciding which of the Amsterdam Mennonite communities to join. Vondel was a member of the Waterlander Mennonite community of Amsterdam, yet in 1637, at the end of her life, his mother Sara just bequeathed a sum of money to the 'Flemish' Mennonite community, suggesting that she was a member of this group.$^{15}$ It is possible that it was she who, later in life, decided to change communities - because Vondel and all his sisters were Waterlanders. An alternative explanation is that she and her husband had always belonged to the Flemish community, but that the children decided otherwise - as most historians have assumed. However that may be, there is no reason to believe that such choices were necessarily accompanied by 'an intense inner struggle', as a recent biographer surmises. ${ }^{16}$ The differences between the communities, however bitter, concerned church order more than doctrine. ${ }^{17}$ In early seventeenth-century Amsterdam there were also practical reasons that might inspire decisions to change community. For the Vondel children, this could have been marriage Joost and his sister both married a brother and sister of the Waterlander De Wolff family. And it was by no means uncommon for doopsgezinden

13 'Toetssteen' (1650), WB 5, p. 492.

14 'Litterae Annuae missionis Hollandicae anno 1641' ed. by Van Lommel in his De historische waarde der Litterae Annuae, pp. 60-69, esp. 66. On the freedom to choose see Pollmann, 'From Freedom of Conscience'.

${ }_{15}$ Sterck, Oorkonden over Vondel en zijn kring, pp. 322 and 328.

${ }^{16}$ Calis, Vondel, pp. 61-62.

${ }_{17}$ Zijlstra, Om de ware gemeente en de oude gronden, p. 273. 
to move from one community to another at some point in their lives. ${ }^{18}$ There is no reason to believe, therefore, that their support for a different 'flavour' of Mennonite community caused a breach between the Vondel siblings and their mother.

Until his late thirties, Vondel's religious trajectory was therefore uneventful. He accepted adult baptism, married a doopgezinde girl, Maaike de Wolff, and from 1616 served as a deacon in his church. In 1620, and again a few years later, he suffered from debilitating attacks of 'melancholy', which for some time made him unproductive. Yet by the mid 1620 s he suddenly resurfaced and took the stage with angry interventions in a series of public debates on religious issues. The first of these related to a conflict within his own community. In 1626, the Waterlander community was deeply divided over the value of Scripture as opposed to any revelations of the Holy Spirit that individuals might experience. Waterlander leader Hans de Ries thought that these were of value, and silenced his opponent Nittert Obbesz who argued that Scripture alone should be the anchor of the faith. In his Antidotum: Tegen het vergift der Geestdryvers: Tot verdedigingh van 't beschreven woord Gods (Antidote to the Poison of the Zealots, in Defence of the Word of God, 1626), ${ }^{19}$ Vondel took the side of Nittert, predicting dire consequences if religion were to be based on random intimations of the spirit. Recalling the embarrassing Anabaptist bids in the 1530s to create a new Jerusalem in the cities of Münster and Amsterdam, he predicted that De Ries's stance 'would make a mockery of Christ, if anyone can believe what he wants and what mills about in his loose and brainless head, so that temples will stand empty and none of the laity will heed the Bible, but will consider Sunday preaching just letterwerk. ${ }^{20}$ Judging by this passage, Vondel's emphasis on Scripture was apparently coupled with a fear of disorder, and desire for certainty and stability in matters pertaining to the faith.

At the same time, Vondel did not like enforced uniformity. In 1619 the political protector of the Remonstrants, Johan van Oldenbarnevelt, had been beheaded for treason, and their preachers had been silenced or banished. When some of the Remonstrants were implicated in a coup against Stadtholder Maurits of Nassau in 1623, the magistrates in some cities in Holland again lashed out with unprecedented force

${ }^{18}$ Kühler, Geschiedenis der doopsgezinden, pp. 5-6.

${ }^{19}$ Zijlstra, Om de ware gemeente, pp. 280-81.

${ }^{20}$ WB 2, p. 808. 
against the dissident Remonstrant communities. Many Waterlander Mennonites sympathized with some Remonstrant viewpoints, but sensibly decided not to become too closely associated with the controversy. ${ }^{21}$ Not so Vondel, however, who now came out in open support of his many Remonstrant friends. He protested against the Calvinist 'conscience-butchers, disguised in the robes of justice, calling upon them to give 'your fellow Christians' the free exercise of their religion. In 1631 he signed a petition to demand freedom of worship for the Remonstrant community. ${ }^{22}$ Apart from voicing his distaste of the forcing of consciences, he also proved strongly opposed to the Reformed take on double predestination. In his Decretum horribile (The Horrifying Judgement, 1631), he outlined the anguish of a young mother with her newborn twins, both cleansed by baptism 'in Christ's loving blood', who asks herself which of the two might be doomed to hell. The poem ends with his reassurance that God will protect both babies as a hen its chicks, and with a vision of paradise. Many Remonstrants before Vondel had been attacking the doctrine of double predestination with the argument that this might condemn innocent babes to hell, so there is no need to connect this to Vondel's biography. ${ }^{23}$ Still, it is interesting to note that the baby twins in his vision had received infant baptism. It is unlikely that we should see this as a rejection of adult baptism, the single most important characteristic of the Mennonite community. Brandt thought that Vondel continued to live as a Mennonite at least until the death of his wife in 1635. But it does perhaps suggest that by the 1630s Vondel was no longer particularly careful to stick to the confessional culture in which he had been brought up. Yearning for certainty he might be, but he was also exercising his right to choose.

\section{Sufferings}

According to Geraardt Brandt, Vondel's distaste for religious persecution could be traced back deep into his family history. Brandt was a Remonstrant preacher, who himself knew the poet and who was well at home in at least some of Vondel's Amsterdam milieu. In the life of Vondel that he published in 1682, three years after the poet's death,

\footnotetext{
${ }^{21}$ Zijlstra, Om de ware gemeente, p. 278.

${ }^{22}$ Leendertz, 'Is Vondel remonstrant geweest'.

23 'Decretum horribile: Gruvvel de verwoestinghe' (1630), WB 3, p. 346. On earlier use of this argument, see Van Deursen, Bavianen en slijkgeuzen, pp. 282-83.
} 
he drew on his own conversations with Vondel, as well as on information that he had gathered from his friends. After introducing his topic Brandt started his account of Vondel's life with a dramatic 'tale of origin':

His maternal grandfather Peter Kranen, a [...] resident of Antwerp, was, together with his spouse, committed to the most defenceless of all the reforming groups, the Mennonites, at the time of the fierce persecutions $[\ldots]$ when placards were in force of which it was said 'that they were written in blood rather than in ink, and he was attending their gatherings in the days when this could cost people their lives. ${ }^{24}$

Indeed, Brandt continued, Kranen was betrayed, and while he himself escaped, his wife, many months pregnant, was arrested and jailed. Although she was briefly allowed to leave prison to give birth, she was again interned and was tried for heresy. Fortunately a cousin had come to her rescue:

When he heard from the Margrave [of Antwerp], that she 'had been condemned to the fire, and would die together with some preacher', he was deeply worried, begged for a reprieve and asked 'if one might not save her by having one of her children baptized as a Catholic by a priest'. The reply was 'perhaps'. And in this hope they hastily called one of the children (who had fled to Cologne with their father) back to Antwerp, where the child was baptized according to the customs of the Roman church: and afterwards the mother, through much begging and pleading, was at last released, having promised to continue to live as a Catholic.

She then went to Cologne to join her husband and children, where they found their refuge, and the daughter who had been baptized by a priest to save her mother was named Sara Kranen, and was later to be the mother of Vondel, our poet. Because the milliner Joost van den Vondel [...] who was also a keen follower of the Mennonites, also went into exile in Cologne because of the persecution, and married that girl $[\ldots] .^{25}$

Cross-checking with other records has shown that Brandt's tale had a basis in reality. Peter Craanen was indeed indicted for attending Mennonite meetings in 1571, and in July 1571 one of his daughters was actually baptized in Antwerp's cathedral aged three and a half, in the presence of a high-ranking Catholic priest. ${ }^{26}$ Yet it is also worth examining this passage as a tale of origin - a tale that was transmitted by the

\footnotetext{
${ }^{24}$ Brandt, 'Het leven van Joost van den Vondel', p. 7.

${ }_{25}$ Brandt, 'Het leven van Joost van den Vondel', p. 8.

${ }^{26}$ De Valk, 'Vondel's grootouders onder Alva om het geloof vervolgd'.
} 
descendants of Sara Craanen and Joost van den Vondel senior and that, by the time it reached Brandt, had probably been told and retold many times. Unsurprisingly, the story had changed shape in the process. Thus it was not in fact Sara, Vondel's mother, 'who had been baptized by a priest to save her mother', but his aunt Anna. ${ }^{27}$ It is also unlikely that Vondel's father, the milliner Joost senior, left Antwerp because of persecution. In 1582, when he departed, Antwerp was fighting on the side of the Revolt and not persecuting Mennonites - like so many others, Joost probably left the city because of the economic downturn. His religious commitment was to be tested, but that happened twelve years later, when Joost senior was harassed and fined for attending Mennonite gatherings in Cologne. At that point he decided yet again to migrate, and took his wife and children to the Dutch Republic, reputedly suffering the discomfort with such patience that their coachman compared the couple to 'Joseph and Mary'. ${ }^{28}$

Stories like these were familiar enough in the Republic. Both in Mennonite and in Reformed circles, tales of martyrdom, persecution and flight figured prominently. As a form of 'imitatio' of the passion and a simile to the history of Israel, they resonated strongly in contemporary piety. Martyrdom and suffering among one's ancestors conferred status on their descendants. It was especially among the tens of thousands of Southern Netherlanders who had come to the Republic rather than abandon their Protestant faith that such tales lived on. For the many families of Brabantine and Flemish extraction, stories of victimhood fulfilled an additional function as a 'tale of origin' and for many it formed the start of their family histories. Moreover, stories like these legitimized and even sanctified their presence as aliens in the Republic. ${ }^{29}$ It is no wonder, then, that in families like that of Vondel such tales were carefully transmitted, and perhaps also adapted in the retelling so as to conform even more closely to expectations or to achieve greater symmetry.

There is one unusual trait in the tale Brandt tells. In the martyrological tradition, for a believer to cave in like Vondel's grandmother Clementia had done, and to allow the Catholic baptism of her daughter, was not necessarily considered a good outcome. True steadfastness

\footnotetext{
27 Ibidem, pp. 98-99.

28 Brandt, 'Het leven van Joost van den Vondel', p. 11

29 Pollmann, Het oorlogsverleden van de Gouden Eeuw. http://www.dbnl.org/tekst/ rome002erfl01_01/rome002erfl01_01_0014.htm
} 
in the Mennonite tradition would have prescribed choosing death rather than make such a compromise. ${ }^{30}$ It is interesting, therefore, that Clementia's concession had remained part of the story - or perhaps reentered it once many in the Vondel family had converted to Catholicism. At the same time, Vondel's respect for the sacrifices of his ancestors was apparently unaffected by his conversion. Brandt reported that the poet:

considered non-Catholics to be heretics but had a good feeling about his grandfather Kranen, and, because of his simple piety, expected the best for him, despite the fact that he had died a non-Catholic.

It may seem surprising that Vondel managed to square his attachment to a family history of suffering and Mennonite piety with a conversion to the same church that his ancestors had abandoned and rejected at such a price to themselves and their family. In the Dutch Republic, stories of the sufferings under Habsburg rule were frequently used to remind people of the iniquities of Rome. There was a powerful discourse that used the memories of the inquisition and Spanish rule to associate Catholicism with violence, and its adherents with enemies of the Netherlands. As we shall see, some of Vondel's friends were to use these arguments to criticize him for his conversion. Yet the Catholic minority in the Netherlands did not fail to point out that Catholics had suffered their own martyrdoms in the Dutch Revolt, and that in the Republic they were being persecuted rather than being the persecutors. Throughout his life, the themes of persecution, exile and sacrifice remained of enormous interest to Vondel, but he was not inclined to see them as a vindication of one brand of Christianity alone.

\section{Conversion}

Many scholars have regretted that Vondel did not describe a conversion experience, and some have tried to reconstruct an alternative for it from his Altaergeheimenissen (Secrets of the Altar) of 1645 or other texts. In his omission to tell us of his experience of conversion, however, Vondel was entirely typical of most sixteenth- and seventeenthcentury converts. There are early modern, emotive conversion narratives in the tradition of Saint Augustine. ${ }^{31}$ Yet in most instances

30 Gregory, Salvation at Stake, pp. 112-87.
31 Fredriksen, 'Paul and Augustine.' 
when early modern people described a 'conversion experience' in that classic sense, they were not talking about a change of denomination, but about a transformation in their relationship with God. Early modern believers who changed religious confession were more often than not silent about their motives for doing so. There are, admittedly, exceptions. In Catholic circles, there was a genre of printed conversion narratives that served propaganda purposes. ${ }^{32}$ Protestants might account for their conversion when they found they needed to justify or explain themselves. Thus both the conversion narratives of Luther and of Theodore de Bèze were written to explain to their readers how it was possible that the religious ideas and sentiments in their later oeuvre differed from those they had expressed earlier. ${ }^{33}$ It was in this tradition that we should place Vondel's Toetssteen (Touchstone, 1650), which formed part of the introductory matter to his collected poems:

If any verse Romish or not edifies or annoys the reader please excuse my pen for those passages and judge the matter by the time in which it was written

Saint Paul followed the trails of his ancestors

Saint Augustine the Manicheans before the bright light appeared to them through which the dark mist disappears.

My youth was bound by inherited teachings to a sect, and one alone, until I, by a clearer sight of things secular and ecclesiastical discovered, at a better day the pearl that had been hidden, and for which all is profitably lost. Happy is he who chooses the best. ${ }^{34}$

While this account of what had made him change religions is very pithy, it is worth noting that it was framed in terms of discovery,

${ }^{32}$ Luria, 'The Politics of Protestant Conversion to Catholicism in Seventeenthcentury France'.

${ }^{33}$ Pollmann, 'A Different Road to God'.

${ }^{34}$ WB, 5, p. 492: 'Indien hier Roomsch of Onroomsch dicht / Den Lezer sticht, of hem ontsticht; / Men schell' mijn pen die vlacken quijt, / En toets' de stof naer heuren tijt. / Sint Pauwels volght der Vadren zeên, / Sint Augustijn de Manicheên, / Eer hun het heldre licht verschijnt, / Waer voor de donkre mist verdwijnt. / Mijn jonkheit bondt door errefleer / Zich aen een Secte, en geene meer, / Tot datme, door een klaerder blijck / Van 't Weereltlijck en Kerckelijck, / Ontdeckt wiert, in een' schooner dagh, / De Perle, die verborgen lagh, / Waer voor men 't al met winst verliest. / Geluckigh die het beste kiest.' 
enlightenment (bright light vs. dark mist) and choice. Forty years earlier, the Mennonite schoolmaster Israel van der Meersch had described his own conversion to Calvinism in terms that were somewhat more emotive, but that also referred to the light that brought truth and that was like a 'pearl. ${ }^{35}$ Believers like these did not describe a conversion as a personality change, but as a process in which they exercised their judgment: 'happy is he who chooses'.

That is not to say, of course, that this choice had been made completely individually. Other people were instrumental in Vondel's choice. Catholic scholars have expended much energy and anger on the question as to who might be credited with having pointed the great poet in the direction of the light. The Jesuits claimed this scalp in 1641, in one of their annual reports to Rome, but since the eighteenth century there has also been a camp that has argued in favour of the vicar Leonard Marius as Vondel's true guiding light. ${ }^{36}$ Not much has been made of the role of Vondel's daughter Anna in this process. Yet it was she who in the Jesuits' report is highlighted as the driving force:

Among the converts were [...] Joost van den Vondel, a poet renowned for his vernacular tragedies, an excellent man and one-time buttress for the Arminian sect, who - when he saw that his only daughter, blessed with an excellent mind and also thoroughly versed in Latin literature, had abandoned Menno at the age of thirty plus, to embrace the camp of the true faith, and, once she had been cleansed by the waters of baptism, also to serve this with perpetual virginity - followed her soon afterwards, together with another child. ${ }^{37}$

Beyond this passage, we know little about Anna - Brandt confirms that she was intelligent, and we also know that she left most of her money to a Catholic charity in Amsterdam. The passage in the 'Litterae Annuae' suggests that Anna may have opted to become a klop or 'spiritual maiden', like many other Catholic women in the Republic did. These lay sisters, of whom there were thousands, formed an important mainstay for the church. ${ }^{38}$ Yet Anna also kept house for her father, and was to extract him from the financial difficulties he experienced later in life, when his hapless son Joost had gone to seed. The chances are that she

\footnotetext{
${ }^{35}$ Pollmann, 'From Freedom of Conscience'

${ }^{36}$ For a taste of the discussion see Van Lommel, De historische waarde.

37 'Litterae annuae', p. 66. Only Brom, Vondels bekering, devoted significant attention to her role.

${ }^{38}$ Spaans, 'Orphans and Students'.
} 
was as important as any priest in suggesting Vondel take a fresh look at the Roman faith.

Nevertheless, there is also evidence of altogether different motives for Vondel to convert. Perhaps because this was one subject upon which he had never dared or wanted to quiz Vondel himself, when coming to the subject of Vondel's conversion, Geraardt Brandt reverted to third-party information. 'A certain reliable jurist' had told him that Vondel had been considering remarrying, and had cast his eye on

a wealthy widow of the Romish persuasion and had started to consider whether he could, in conscience, follow her in this. That he had, in conversation about this matter with this jurist and others, first cast doubt on everything, and said in the end that there was no certainty to be had about religion, unless one were prepared to accept an infallible judge and explainer of all disputed points, and acknowledged on earth one Stadtholder of Christ, and that this led to the Pope as the successor of Peter, and the Roman church with its authority, and all the more so because some priests and other religious, hoping to gain a man of such renown, did their best for it. ${ }^{39}$

For obvious reasons, Catholic scholars have never liked this story. ${ }^{40} \mathrm{Of}$ course it may well have been true; it was not unknown for people in the Dutch Republic to convert in order to please their spouses, although that would not explain why Vondel proceeded to also dedicate so much of his subsequent literary output to Catholic themes. Alternatively, it may well be that in this story we simply have the gossip that Vondel's Remonstrant friends used to rationalize what to them was an unimaginable choice for Rome. While they knew and acknowledged that Vondel was not himself a Remonstrant church member, they had long seen Vondel as their hero. Their dismay at his conversion is therefore easily understandable, and all the more so since Vondel now seemed to confirm the old Reformed charge that Arminians were 'crypto-Catholic'. After Vondel had flaunted his new allegiance by publishing his Secrets of the Altar, a number of Remonstrants decided to take the poet to task. In a pamphlet entitled Kracht des geloofs van [...]Joost van Vondelen (The Power of the Faith of Joost van den Vondel), his former friend Jacob Westerbaen lashed out against the convert. How could someone who had fought against the tyranny of Geneva now sell out to

\footnotetext{
39 Brandt, 'Het leven van Joost van den Vondel' pp. 45-46.

${ }^{40}$ See, for example, Wijnman, 'Cherchez la femme bij Vondel's overgang tot het katholicisme'.
} 
the Roman yoke, he asked? He discredited Vondel by suggesting that he was fickle and easily influenced - all that was needed for him to become Jewish (joots), he sneered, was for him to swap the last two letters of his name. ${ }^{41}$ Another poet, hiding behind the single initial P., wrote:

If a righteous man lives by faith

How much better off, then, Mr. Vondel, you are than others

When your old [faith] gives out, you just get yourself a new one.

Those beasts thrive best that often change their pasture. ${ }^{42}$

No wonder, then, that Brandt felt he needed to offer a rationalization of Vondel's conversion. He added that his friend had been so busy with his poetry that he was simply a bit ignorant about religion.

Yet before dismissing the passage about the rich Romish widow altogether, it is worth considering the line of reasoning that Vondel is alleged to have used: 'that there was no certainty to be had about religion, unless one were prepared to accept an infallible judge and explainer of all disputed points, and acknowledged on earth one Stadtholder of Christ, and that this led to the Pope.' Vondel's argument proceeds from what was a very modern viewpoint, rather Hobbesian in flavour, that there is no clear basis on which people can ever agree on religion. For the 'Vondel' in Brandt's account, as for Hobbes, this creates an unacceptable situation, which demands the acceptance of one 'infallible' arbiter. Very much unlike Hobbes, 'Vondel' then concludes that this arbiter might as well be the Pope. In many ways this account actually fits quite well with what we know about Vondel's interests in religion, and with those of many Protestant contemporaries. The passage chimes with Hugo Grotius's project to reunify the churches, in which Vondel had been extremely interested. And although Vondel's later claim that Grotius had considered opting for Rome himself was spurious, it is quite possible that for Vondel, it was a Grotian quest to try and define core values in Christianity that resulted in his choice for Rome. ${ }^{43}$

This reported conversation is therefore well worth taking seriously even if it is difficult to say whose narrative we have here. Was Vondel

${ }^{41}$ [Jacob Westerbaen], Kracht des geloofs van den voortreffelijcken ende vermaerden Nederduytschen poeët, Joost van Vondelen, te speuren in de Altaer-geheymenissen, by sijne e. ontvouwen in drie boecken \&c (Schiedam, 1648).

${ }^{42}$ P., 'Toegift aen Sr. Joost van Vondel op sijne e. spreucke, ghestelt op den tijtel Altaer-Geheymnissen' in [Westerbaen], Kracht des geloofs, unpaginated.

${ }^{43}$ Nellen, Hugo de Groot, chapters XV-XVI, pp. 581, 587; Calis, Vondel, p. 129. 
trying to explain his conversion in terms his friends would understand? Or was this really the route by which he had arrived at his choice? Although it is impossible to decide this with any certainty, it is worth noting that he was not the only Dutch convert to Catholicism who explained his decision with such arguments. His acquaintance and fellow convert Maria Tesselschade Roemers was also pushed by disapproving Protestant friends to explain herself. One of these, the Arminian theologian Caspar van Baerle, reported to a friend:

She has got it into her head that only a few articles are needed for the faith, and that what she has from the Roman church is in accordance with the ceremonies and customs of the ancients - the rest is not for a laywoman to worry about and investigate. The errant [woman] really likes Grotius's declaration, and, using his authority, is difficult to shift from her proposition. ${ }^{44}$

By claiming that as 'a laywoman' she did not have to worry about theological niceties, Tesselschade was neatly playing the gender card. Yet this was clearly also nonsense. If she had the ability to read and sympathize with Grotius's proposals for unity, she was also well up to making a reasoned decision to convert to Catholicism. And what she gave by way of explanation is very similar to the one Vondel was alleged to have given: 'only a few articles are needed for the faith' and Rome has the best claims to antiquity and thus to authority.

In Vondel and Tessel, then, we can detect the outline of one route by which moderate Protestants in a multiconfessional society might end up converting to Catholicism. Like many Protestants before them had done when confronted with the disagreements between the churches, they thought that one might reach consensus about a core of essential beliefs. ${ }^{45}$ However, whereas this moved some Christians to argue that no one could decide for another person what the truth in religion was, Vondel and Tessel were yearning for authority and unity, and were prepared to grant this to Rome.

By making this decision, Vondel exercised the right to choice that he had valued for a long time. It gave him the certainty that he had long considered essential in the faith. The decision did not require him to change his social network - quite the opposite, he maintained his many

${ }^{44}$ Letter from Caspar van Baerle to Constantijn Huygens, 8 June 1642, in Worp, Een onwaerdeerlycke vrouw, p. 264.

${ }^{45}$ Kaplan, Divided by Faith, pp. 127-43. 
contacts in the Mennonite and Remonstrant communities. Neither did it mean that he abandoned his commitment to the Republic or its values - rather, because he was steeped in a confessional culture that privileged histories of suffering and sacrifice, he could easily transmit his loyalty to a Catholic community which cherished its own victimhood as a clandestine minority religion in a Reformed country. Seen from this perspective, it was perfectly plausible for the Mennonite Joost van den Vondel to have moved to new Catholic pastures, and to have done so 'in conscience'. 